April L. Wright, Raymond F. Zammuto, Peter W. Liesch, Stuart Middleton, Paul Hibbert, John Burke and Victoria Brazil (2016)

\title{
Evidence-based Management in Practice: Opening up the Decision Process, Decision-maker and Context
}

Evidence-Based Management (EBM) has been subject to a number of persuasive critiques in recent years. Concerns have been raised that: EBM over-privileges rationality as a basis for decision-making; 'scientific' evidence is insufficient and incomplete as a basis for management practice; understanding of how EBM actually plays out in practice is limited; and although ideas were originally taken from evidence-based medicine, individual-situated expertise has been forgotten in the transfer. To address these concerns, we adopted an approach of 'opening up' the decision process, the decision-maker and the context (Langley et al., 1995). Our empirical investigation focuses on an EBM decision process involving an operations management problem in a hospital emergency department in Australia. Based on interview and archival research, we describe how an EBM decision process was enacted by a physician manager. We identify the role of 'fit' between the decision-maker and the organisational context in enabling an evidence-based process and develop insights for EBM theory and practice.

Keywords: Evidence-based management, context, healthcare management, qualitative methods 
April L. Wright, Raymond F. Zammuto, Peter W. Liesch, Stuart Middleton, Paul Hibbert, John Burke and Victoria Brazil (2016)

\section{Introduction}

Over the past decade, there has been increasing interest in developing an evidence-based approach to management decision-making (Pfeffer and Sutton, 2006; Rousseau, 2012; Rousseau, 2006; Tranfield, Denyer and Smart, 2003). Observing how evidence-based practice has enhanced patient care in medicine (Sackett, Rosenberg, Gray, Haynes and Richardson, 1996), leading management scholars argue that decision processes within organisations can be similarly improved by systematic analysis of 'best available evidence' (Pfeffer and Sutton, 2006; Rousseau, 2006). The Oxford Handbook of Evidence-Based Management describes EBM as the "science-informed practice of management", which fundamentally involves "using scientific knowledge to inform the judgment of managers and the process of decision-making in organizations" (Rousseau, 2012, p. xxiii). Advocates of EBM see its potential to help bridge the research-practice gap in organisations through management educators incorporating EBM in their teaching (Casio, 2007; Erez and Grant, 2014; Pfeffer and Sutton, 2007; Rousseau and McCarthy, 2007; Rynes, Bartenuk and Daft, 2001; Rynes, Giluk and Brown, 2007), contributing to the relevance of business schools (Bennis and O'Toole, 2005; Thomas and Wilson, 2011).

Other scholars, however, are more cautious of EBM's applicability to management decision-making in practice and offer four particular critiques. First, EBM privileges science and rationality as the basis for decision-making, even though what 'counts' as legitimate evidence in management studies is contested (Arndt and Bigelow, 2009; Learmonth, 2006; Tourish, 2013). Second, given the divergent nature of the management discipline in terms of research questions and methods, Tranfield and co-authors propose "there is a need to recognize that evidence alone is often insufficient and incomplete, only informing decisionmaking by bounding available options" (Tranfield et al., 2003, p. 219). Third, authors have also argued that empirical research into the effectiveness of EBM is not well developed 
April L. Wright, Raymond F. Zammuto, Peter W. Liesch, Stuart Middleton, Paul Hibbert, John Burke and Victoria Brazil (2016)

(Arndt and Bigelow, 2009; Swan et al., 2012) and offers limited insight into the nuances of how EBM plays out as a decision process in practice in different organisational contexts (Reay, Berta and Kohn, 2009; Walshe and Rundall, 2001). Fourth, concerns have been raised that in EBM's borrowing of ideas from evidence-based medicine, the importance of the situated expertise of the decision-maker in making judgments has been lost (Morrell, 2008).

With these four critiques of EBM in mind, we propose that the approach of Langley and co-authors (1995) of 'opening up' decision processes offers a means of advancing understanding of EBM (Langley, Mintzberg, Pitcher, Posada and Saint-Macary, 1995). Specifically, Langley and co-authors (1995) proposed that deeper insights are uncovered when decisions are investigated in ways that 'open up' the role of the decision-maker and of the context in the processes leading to the commitment to action. In the remainder of the paper, we apply this approach with the aim of exploring how the decision-maker and the decision context shape EBM decision processes in practice. We first provide a brief review of the literature on decision processes and EBM before describing the case study method we adopted for our empirical investigation. We then present the findings of our case study which focused on the decision to solve an operations management problem in a hospital emergency department in Australia. Our paper concludes with a discussion of theoretical contributions to the four critiques of EBM and implications for management practice.

\section{Evidence-based management and decision-making}

Evidence-based management is an emerging stream in the literature on decision-making in management and organisation studies. For several decades, scholars have been interested in understanding how decisions happen in organisations (Butler, 1990; March, 1988, 1991; Mintzberg and Waters, 1990), as well as prescribing processes for how decisions should be made (Nutt, 2008). Decision processes are typically thought to involve a stimulus for action 
April L. Wright, Raymond F. Zammuto, Peter W. Liesch, Stuart Middleton, Paul Hibbert, John Burke and Victoria Brazil (2016)

and a commitment to action (Mintzberg, Raisinghami and Theoret, 1976) although the traces of decisions inside organisations are not always clear (Mintzberg and Waters, 1990).

Historically, the literature on decision processes in organisations is broadly grouped into rational, political and garbage can perspectives (Das and Teng, 1999; Eisenhardt and Zbaracki, 1992). Within the rational perspective, decision-makers approach decisions as intendedly rational choices (March, 1991) and try to follow a systematic process of problem identification, search for and generation of alternative courses of action, and evaluation of these alternatives (Daft, 1995). However, because limits on information and human cognition place boundaries on rationality (Simon, 1955; Simon, [1945]1997), decision-makers look for new alternatives in the vicinity of current actions, select an alternative that is 'good enough' in satisfying evaluation criteria rather than the optimal solution, and proceed when there is sufficient consensus (Cyert and March, 1963; March and Simon, 1958; Simon, 1976; Thompson, 1967). Other scholars emphasise that decision processes involve political bargaining because organisations are coalitions of people with competing interests and power (Allison, 1971; Pettigrew, 1973; Pfeffer and Salancik, 1974). Finally, decision-making in some organisations may resemble an organised anarchy in which solutions randomly meet up - as if in a 'garbage can' - with participants, choice opportunities and problems (Cohen, March, and Olsen, 1972; Padgett, 1980).

Of these three perspectives, bounded rationality is normatively prescribed as the approach that decision makers should adopt (Van de Ven and Lifschitz, 2013). Empirical studies have found that some organisations do engage in bounded rational processes. Mintzberg's early work reported a process involving three phases (Mintzberg et al., 1976): an identification phase recognising problems and opportunities and diagnosing cause-and-effect relationships; a development phase searching for and/or designing solutions; and a selection phase screening solutions for feasibility, investigating alternatives and selecting a course of 
April L. Wright, Raymond F. Zammuto, Peter W. Liesch, Stuart Middleton, Paul Hibbert, John Burke and Victoria Brazil (2016)

action. Nutt (1984) found organisations made decisions using different combinations of problem formulation, development of alternatives, detailing of viable alternatives, evaluation of alternatives and implementation. Other studies similarly concluded that different stages may be skipped, repeated, extended, or re-ordered depending on the type of decision and the decision-making environment (Eisenhardt, 1989a; Hickson, Butler, Cray, Mallory and Wilson, 1986; Klingebiel and De Meyer, 2013; Langley, 1989; Laroche, 1995; Mintzberg et al., 1976; Nutt, 1984; Plambeck and Weber, 2009; Sutcliffe and McNamara, 2001; Witte, 1972).

Studies also provide empirical support for a link between decision processes and outcomes (Rodrigues and Hickson, 1995). The rational perspective of 'thinking first' works best when "the issue is clear, the data is reliable, the context is structured, thoughts can be pinned down, and discipline can be applied" (Mintzberg and Westley, 2001, p. 91). Decisionmaking is more effective in structured contexts when decision-makers rely on analysis of relevant information when generating, evaluating and selecting among alternatives (Dean and Sharfman, 1996; Fredrickson, 1984; Nutt, 2008), whereas intuition becomes important in unstructured task situations and high-stress or fast-paced environments (Dane and Pratt, 2007; Eisenhardt, 1989a; Mintzberg and Westley, 2001; Useem, Cook and Sutton, 2005). Intuition is based on sensing and feeling grounded in a decision-maker's expertise, experience and perceptions (Miller and Ireland, 2005; Mintzberg and Westley, 2001; SadlerSmith and Shefy, 2004).

The emerging literature on evidence-based management is an extension of the rational perspective on decision-making (Baba and HakemZadeh, 2012). As an approach to decision making informed by the best available evidence, EBM encourages management practitioners to consider how different sources of evidence can be incorporated into decision processes (Pfeffer and Sutton, 2006; Rousseau and McCarthy, 2007). EBM involves "the conscientious, 
April L. Wright, Raymond F. Zammuto, Peter W. Liesch, Stuart Middleton, Paul Hibbert, John Burke and Victoria Brazil (2016)

explicit, and judicious use of four sources of information: practitioner expertise and judgment, evidence from the local context, a critical evaluation of the best available research evidence, and the perspectives of those people who might be affected by the decision" (Briner, Denyer and Rousseau, 2009, p. 19). While searching for and evaluating information about alternatives has been present historically in rational decision making models, EBM represents a refinement in scholarly thinking about the relevance and reliability of different types of evidence - especially research evidence - as inputs into decision processes.

However, although scholars speculate that managers can incorporate 'best available evidence' into the stages in rational decision-making, prescriptions for how this might occur are ambiguous (Baack, 2007) and empirical research into EBM in practice is lacking (Briner et al., 2009). Healthcare management research exemplifies these critiques of EBM. Studies show limited adoption of EBM in healthcare management in practice (Kovner, Elton and Billings, 2000; Kovner and Rundall, 2006; Swan et al., 2012). While Walshe and Rundall (2001) argue the complex, time-dependent and political characteristics of management decisions may undermine the utility of EBM, more recent research suggests EBM can be fruitfully applied to operational, strategic and core business transaction management of health services (Kovner and Rundall, 2006; see also Swan et al., 2012).

Echoing the general critiques of EBM, healthcare management decisions are made in complex organisational contexts where: the use of evidence does not necessarily lead to anticipated outcomes (Arndt and Bigelow, 2009); evidence is "an artifact of the social processes that lead to its creation" in terms of selection of questions, methods and outcome definitions (Arndt and Bigelow, 2009, p. 209); and evidence must be mobilised by a decisionmaker and co-produced with other decision-makers and stakeholders (Swan et al., 2012). Thus, scholars have called for greater attention to the process of application of EBM by particular decision-makers in particular contexts. Our paper seeks to fill the gap on the 
April L. Wright, Raymond F. Zammuto, Peter W. Liesch, Stuart Middleton, Paul Hibbert, John Burke and Victoria Brazil (2016)

process and particularities of EBM. It does so through a study of how evidence was gathered and applied by a decision-maker in a health services organisation facing an operations management problem.

\section{Methods}

\section{Research Design}

We identified an opportunity to study of EBM during a broader research project at a large metropolitan hospital in Australia. During data collection, we became aware of a situation in which physicians in the Emergency Department (ED) seemed to solve an operations management problem through an evidence-based approach. The problem concerned inefficient work practices in a unit within the ED called Fast-Track which dealt with patients whose conditions could be treated rapidly and discharged. We identified the Fast-Track decision process as a unique opportunity to explore EBM inside an organisation; as Rousseau (2006) notes, such case studies are rare. Our case study fits Kovner and Rundall's (2006) classification as an operational management problem in health services management and, as shown in Table 1, the decision characteristics match Walshe and Rundall's (2001) criteria for distinguishing 'typical' management decisions from clinical decisions.

The Fast-Track decision process extended over a four-year period and involved multiple participants and organisational constraints. The ED established two internal working parties to resolve Fast-Track's problems without success. A management consulting firm then provided recommendations, including assigning a separate workforce of nurses and senior doctors to Fast-Track. Recommendations were not implemented because ED staff resisted changes being imposed on them by an external review. 
April L. Wright, Raymond F. Zammuto, Peter W. Liesch, Stuart Middleton, Paul Hibbert, John Burke and Victoria Brazil (2016)

TABLE 1: Characteristics of Fast-Track Case Study

\begin{tabular}{|c|c|c|c|}
\hline $\begin{array}{l}\text { Characteristics } \\
\text { of Decisions }\end{array}$ & $\begin{array}{l}\text { Clinical } \\
\text { Decision } \\
\text { Making }\end{array}$ & $\begin{array}{l}\text { Health Care } \\
\text { Management } \\
\text { Decision Making }\end{array}$ & Fast-Track Case Study \\
\hline Time frame & $\begin{array}{l}\text { Many clinical } \\
\text { decisions } \\
\text { taken every } \\
\text { day }\end{array}$ & $\begin{array}{l}\text { Fewer, larger } \\
\text { decisions taken }\end{array}$ & $\begin{array}{l}\text { Decision on a single large project with important } \\
\text { consequences for staff and patients, following } \\
\text { four years of unsuccessful change initiatives by } \\
\text { two internal working parties and one external } \\
\text { management consultant group. Consistency with } \\
\text { management decision-making = High }\end{array}$ \\
\hline Participants & $\begin{array}{l}\text { Mostly by } \\
\text { individual } \\
\text { clinicians }\end{array}$ & $\begin{array}{l}\text { Usually by or in } \\
\text { groups, often } \\
\text { requiring } \\
\text { negotiation or } \\
\text { compromise }\end{array}$ & $\begin{array}{l}\text { Decision could not be made by a single } \\
\text { individual. Negotiation needed with different } \\
\text { professional groups whose responsibilities and } \\
\text { workloads would be impacted (doctors, nurses, } \\
\text { physiotherapy, radiology, other allied health } \\
\text { services) and with hospital administration and } \\
\text { executive to approve and fund changes to } \\
\text { physical layout and job design. Consistency } \\
\text { with management decision-making = High }\end{array}$ \\
\hline Constraints & $\begin{array}{l}\text { Few } \\
\text { constraints on } \\
\text { the } \\
\text { individual's } \\
\text { decision }\end{array}$ & $\begin{array}{l}\text { Many } \\
\text { organisational } \\
\text { constraints }\end{array}$ & $\begin{array}{l}\text { Organisational constraints related to physical } \\
\text { space (space allocated to Fast-Track reduced } \\
\text { space available for treatment of more urgent and } \\
\text { seriously ill patients); financial cost } \\
\text { (refurbishment, staffing); industrial relations } \\
\text { (workloads and shift rosters); equipment } \\
\text { availability; training obligations (teaching } \\
\text { hospital). Consistency with management } \\
\text { decision-making = High }\end{array}$ \\
\hline Nature & $\begin{array}{l}\text { Decisions } \\
\text { homogeneous, } \\
\text { involving the } \\
\text { application of } \\
\text { a general body } \\
\text { of knowledge } \\
\text { to specific } \\
\text { circumstances }\end{array}$ & $\begin{array}{l}\text { Decisions are } \\
\text { heterogeneous } \\
\text { and less based on } \\
\text { applying a general } \\
\text { body of } \\
\text { knowledge to } \\
\text { specific } \\
\text { circumstances }\end{array}$ & $\begin{array}{l}\text { Decision pertained to an operations management } \\
\text { problem faced by all EDs for which there exists } \\
\text { a diversity of possible responses and a nascent } \\
\text { body of research comparing those responses. } \\
\text { Consistency with management decision- } \\
\text { making = Focused (fits with operations } \\
\text { management in health services management, } \\
\text { Kovner and Rundall, 2006) }\end{array}$ \\
\hline Supports & $\begin{array}{l}\text { Long tradition } \\
\text { of using } \\
\text { decision } \\
\text { support } \\
\text { systems }\end{array}$ & $\begin{array}{l}\text { No tradition of } \\
\text { using any } \\
\text { decision support }\end{array}$ & $\begin{array}{l}\text { Tradition of using decision support systems for } \\
\text { clinical decisions but use of research evidence to } \\
\text { support management decisions only emerging in } \\
\text { hospital. Consistency with management } \\
\text { decision making = High }\end{array}$ \\
\hline Results & $\begin{array}{l}\text { Results of } \\
\text { decisions often } \\
\text { relatively } \\
\text { clear, and } \\
\text { some } \\
\text { immediate } \\
\text { feedback }\end{array}$ & $\begin{array}{l}\text { Results of } \\
\text { decision and } \\
\text { causal } \\
\text { relationship } \\
\text { between decision } \\
\text { and subsequent } \\
\text { events and } \\
\text { feedback often } \\
\text { difficult to } \\
\text { determine }\end{array}$ & $\begin{array}{l}\text { Although it was clear to ED staff and hospital } \\
\text { executive that Fast-Track was not working, it } \\
\text { was difficult to determine and reach agreement } \\
\text { on the cause of the problem - which is why it } \\
\text { had persisted for four years. Consistency with } \\
\text { management decision-making = High }\end{array}$ \\
\hline
\end{tabular}

Table adapted from Walshe and Rundall (2001, pp. 440 - 441) 
April L. Wright, Raymond F. Zammuto, Peter W. Liesch, Stuart Middleton, Paul Hibbert, John Burke and Victoria Brazil (2016)

Over the next two years, senior physicians took ownership of the strategic direction of the ED. In 2008, Dr Clancy (a pseudonym) acquired the ED's Patient Flow Portfolio. Dr Clancy spent $80 \%$ of his work time performing a clinical role and the remaining $20 \%$ was devoted to managing his portfolio, which included Fast-Track. Dr Clancy was trained as an evidence-based medical practitioner but did not have any formal management training. Associated with the field site hospital for 11 years, he was familiar was Fast-Track's contested management history. Our analysis focuses on the evidence-based process Dr Clancy enacted to successfully reform Fast-Track.

\section{Data Collection and Analysis}

We collected data retrospectively because the redesign of Fast-Track preceded our involvement at the field site. While retrospective case studies offer advantages of efficient and focused data collection (Leonard-Barton, 1990), they have potential biases of informants inaccurately recalling events and desiring to present themselves and their organisation in a positive light (Golden, 1992). To minimise biases, we utilised multiple informants to allow cross-checking of information (Eisenhardt, 1989b), focused on knowledgeable informants at executive and clinical levels and encouraged free rather than forced recall (Miller, Cardinal and Glick, 1997) and moved beyond interview self-reports and triangulated with archival documents (Leonard-Barton, 1990).

We conducted interviews with 24 emergency physicians and registrars, four hospital executives and one nurse who had been heavily involved in the design of Fast-Track. Each interview was conducted by two members of the research team at the field-site, lasted one hour on average and was digitally recorded and transcribed. Interviews were semi-structured to allow the opportunity for probing and clarification (Flick, 2002). In addition to questions focused specifically on decision-making processes, our interview protocol included questions 
April L. Wright, Raymond F. Zammuto, Peter W. Liesch, Stuart Middleton, Paul Hibbert, John Burke and Victoria Brazil (2016)

about professional values, identity and training as part of the larger research project. For similar reasons we also collected observations of the work of emergency physicians in overseeing patient flow through the hospital ED, including in the physical space designated as Fast-Track, over a two-year period. While not explicitly analysed in our case study, these observations increased the robustness of our interview data by building trust with key informants and giving us familiarity with ED work flow to facilitate meaningful probing.

In addition to the 29 interviews focused on the reform of Fast-Track, another researcher associated with the overarching project conducted 22 interviews with emergency nurses. These interviews provided background information and insights into the daily work practices of nurses in the ED, including their activities in Fast-Track. Interview data collection was augmented with internal organisational documents and publicly available records.

We analysed the data using inductive procedures recommended for case studies (Eisenhardt, 1989b; Eisenhardt and Graebner, 2007; Miles and Huberman, 1994). Drawing upon analytical methods recommended by Corbin and Strauss (2008), the first author reviewed all of the interviews and documents and performed open coding using 'sensitising questions' of what is being done, when, by whom and why. Statements relating to a similar stage of decision making were grouped into preliminary categories and assigned descriptive labels (Miles and Huberman, 1994) which were iteratively refined by the research team. Table 2 reports representative data from this coding. 
April L. Wright, Raymond F. Zammuto, Peter W. Liesch, Stuart Middleton, Paul Hibbert, John Burke and Victoria Brazil (2016)

\section{TABLE 2: Representative Data for Coding Categories}

\section{Category Representative Data}

Problem

Recognition and Assigning a Mandate
Flow is an important thing to try and maintain functionality. ... We've just got to keep looking at different things and improve specific patient's care. (I-16)

Despite good intentions, this clinical area has consistently failed to meet expectations, and efforts to identify the underlying reasons for this poor performance have not translated into sustainable solutions (Working Party Update).

When I was a resident here, Fast-Track was the least well supported area. If we were short staffed, Fast-Track was the first place we took staff away from ... which meant our waiting times were terrible, our did-not-wait times were terrible, patient complaints I'm sure were very high and it was a very unsatisfying shift working. (I-8)

I think to some extent we wanted to try something because it wasn't working what we were doing and we needed to get better. (I-19)

We knew we needed to look at those processes. Clancy was the one who put his hand up and I guess as a group, we all said, 'Well, we trust that you are going to go off and do a good job.' (I-5)

Any way of actually providing us with some direction is a good thing. So I think there was a lot of backing for Clancy to do that. ... senior backing. (I-12)

Clancy can give you his little summary of all the literature that he's made that literally is that thick of journal articles and his own summary. There's lots of things that are tried. There's no magic bullet. (I-16)

The rest of the country and internationally people talk about what we can do to improve patient flow in terms of Fast-Track, different ways of streaming patients. So I guess Clancy has probably thought about this a bit more. (I-3)

Clancy did a lot of research, presented a lot of statistics as to what he thought ... Clancy loves doing all those figures and numbers. (I-5)

If you're trying to work out a problem, gather the data about it. (I-14)

Cross- $\quad$ I was also quick to acknowledge the fact that I had adapted a lot of other people's pollinating Evidence and Reformulating the Problem ideas just to develop an understanding of why it hadn't worked the first time. (I-Dr Clancy)

Through good careful analysis, there's a better way of doing patient flow. (I-21)

Clancy put in a lot of intellectual time and initiative to try and make something work. (I-20)

He's also one to be a little bit more rational in his thinking ... They're usually good ideas. They're well thought out. (I-29 - Executive).

When Clancy went and did all the research and all the papers that have been published about this stuff, he came up with a set of recommendations which were almost exactly the same as a set of recommendations made by one of the nurses who had a lot of experience in that area. (I-17) 


\section{Category Representative Data}

\section{Engaging \\ Stakeholders \\ and Generating \\ Evidence- \\ Based \\ Alternatives}

Commitment to an Evidencebased Solution and

Implementation
There's a huge amount of thought and time and effort. Clancy didn't just come to us with an idea. He came to us with an idea and all the data that supported it. Like he just threw it out there and it just made sense. (I-9)

Clancy had the input of nursing staff and had to engage them because it made a difference to how they practised. (I-8)

I tried to have a couple of meetings where I'd involve people who I thought were key stakeholders locally. It wasn't the kind of thing I thought required involvement of anyone outside the department for fast tracking - it's discharged patients, it doesn't really involve other members of the hospital. (I-Dr Clancy)

He had enough evidence to support the fact that Fast-Tracks do help, other people are doing it, that it wasn't hard to be convinced to give it a go. (I-19)

I have no interest to go and do all of the same research that Clancy has so I am kind of relying on the fact that he has gone and done all of that work. He has presented me with a model. It seems like a good model to me. I am happy to go along with it. (I-5)

I looked at what caseload I thought should be managed by Fast-Track then working out how many people that actually translated to and what are their cumulative lengths of stays now, what would I hope they would be, how many hours of bum on seat is that going to be, how many cubicles will I need. So I sort of did those things. (I-Dr Clancy)

Clancy diagnosed some problems, said this is how I think it should happen. We trusted him enough to try and that had good results. (I-17)

The way the new Fast-Track is modelled it is a lot easier to get patients in and out quickly because you have got three dedicated beds, they are almost always free, you have got a dedicated nurse and it is more about the patient selection and the patients that are going there. ... (I-24)

Evaluation of Outcomes

Fast-Track is great. It is a simple efficiency manoeuvre that is also better for patients. (I-21)

Great positive feedback for the organisation and then great positive feedback from outside the ED because our numbers have started getting better. We perform well on our times and part of that is a result of Fast Track. (I-17)

It makes for a very satisfying morning when you can just see quick simple things, treat them and dispose of them appropriately. I find that is a lot more satisfying, in terms of being able to provide quick and appropriate care, so that is good. (I-24)

Patient satisfaction-wise .... you actually get the automatic feedback from them, especially since a lot of them have unfortunately been on the flip side of it a few years before or have heard stories or know of people. And so to now come up, have your wound sutured and be home within half an hour, they're always amazed and grateful. So it's really nice to actually see people satisfied with the service - which is the way it should be. (I-23) 
April L. Wright, Raymond F. Zammuto, Peter W. Liesch, Stuart Middleton, Paul Hibbert, John Burke and Victoria Brazil (2016)

We completed our analysis by using our coding to generate a narrative that represented "a relatively complete rendering of the story" of Fast-Track (Eisenhardt and Graebner, 2007, p. 29). In doing so, we also identified and coded additional categories of data that, as we shall discuss later, related to the importance of a 'fit' between the organisational context of the decision process and the decision-maker's personal characteristics. As a confirmability check, we sought feedback from key informants who were involved with FastTrack, including the emergency physician who led the redesign of the unit, that our case narrative was a faithful representation of their experience (Denzin, 1989). In the presentation of findings that follows, we identify quotes from interviews as I-1 to I-29.

\section{Findings}

We present the findings from the study in two sections. We first outline the EBM decision process stages that were enacted in the reorganisation of Fast-Track. We follow this by 'opening up' the decision-maker and context (Langley et al., 1995) with a particular focus on the role these played in the success of the EBM decision process.

\section{The EBM decision process}

We identified five major stages in the decision process, which we present below.

\section{Problem Recognition and Assigning a Mandate}

When Dr Clancy took over leadership of the patient flow portfolio, there was shared recognition among ED staff that Fast-Track was a problem: 'We all recognised that we needed to do something' (I-12). Increases in ED overcrowding created pressure to manage resources with 'optimal efficiency' and make the Fast-Track area 'more functional' in caring for patients (Working Party Report). As one physician noted, 'Everyone knew it was one of 
April L. Wright, Raymond F. Zammuto, Peter W. Liesch, Stuart Middleton, Paul Hibbert, John Burke and Victoria Brazil (2016)

those things that should have been done well and hadn't been, and we were happy to make it a priority' (I-5). Thus, Dr Clancy was 'given the mandate by the team' (I-4) of senior physicians to resolve the problems with Fast-Track.

The hospital's executives were supportive of an internal change agent within the ED taking responsibility for patient flow after department resistance to the management consultancy group's recommendations two years prior. An executive claimed, 'I'm not a big fan of management consultants. But [instead] you let doctors think up their own ideas and support them' (I-28). Assigning Clancy ownership of the problem triggered the next stage in the EBM process for, as one interviewee explained, it meant:

"We had someone in the trenches preparing and collecting data and being methodical about it and then preparing a good evidence-based response to the problem." (I-12)

\section{Assembling Literature and Internal Evidence}

Dr Clancy approached his mandate by collecting both internal and external evidence relevant to the problem. Clancy was both systematic and open-minded during evidence collection.

Consistent with the medical profession's scientific empiricism, he sought to bracket any potential biases that might have arisen from his personal experience of Fast-Track by following the evidence:

"In terms of gathering the evidence, it wasn't just a case of find the evidence to prove or disprove what I wanted to do. ... I went out there and I read it all and the answers started to just come out of the woodwork". (Dr Clancy)

Dr Clancy began with a literature review of patient flow studies in Emergency Departments. Searching peer-reviewed scientific journals, Clancy identified 24 articles most relevant to the problem of streaming ED patients who have short processing times (11 Australian studies, 13 international studies). He systematically reviewed each article in terms of the intervention (what strategy, activity, or structural design is being studied?), 
April L. Wright, Raymond F. Zammuto, Peter W. Liesch, Stuart Middleton, Paul Hibbert, John Burke and Victoria Brazil (2016)

methodology (what data are collected using what methods?), and outcomes (what are the outcomes of the intervention?). Articles selected for review applied concepts from operations research in organisation and management studies to hospitals, including queuing theory, process mapping, process re-engineering, lean thinking, six sigma and change management. Clancy subsequently used the language of operations management in his reports and spoke in his interview of 'wearing my operational efficiency hat'.

In addition to his systematic review of external evidence about patient streaming strategies in hospitals, Clancy assembled internal data about patient flow in his local context. The ED in our case study used an electronic patient tracking system, the Emergency Department Information Systems (EDIS). For every service episode, staff entered data into EDIS to record patient registration, basic clinical decision-making, patient movements and laboratory tests. Clancy accessed EDIS data to develop a baseline understanding of patient flow. Other evidence was available to Clancy in the reports of previous working parties and the management consulting group. These reports presented stakeholder and management consultant perspectives on the causes of Fast-Track's problems, recommended solutions, and evaluated the outcomes of those solutions which had been implemented.

\section{Cross-Pollinating Evidence and Reformulating the Problem}

After assembling the evidence he appraised to be most relevant to the problem, Dr Clancy looked for patterns within and between the different sources of evidence using an approach resembling the iterative analysis of qualitative researchers (Eisenhardt, 1989b; Miles and Huberman, 1994). Clancy described a process of 'cross-pollinating all this information' to help inform decision-making about Fast-Track. He tested insights from the literature review against the EDIS data to assess the applicability of different streaming strategies to the local hospital context. At the same time, when patterns emerged in the EDIS data, Clancy 
April L. Wright, Raymond F. Zammuto, Peter W. Liesch, Stuart Middleton, Paul Hibbert, John Burke and Victoria Brazil (2016)

integrated insights from the literature to explain the underlying 'reasons'. As analysis proceeded, the patterns from EDIS and the literature began to converge into a set of tentative 'ideas' about possible models for reforming Fast-Track which he assimilated with the recommendations of previous working parties and the management consulting group:

"Some things just keep coming up over and over and over again. You've already heard a million ideas and you read a lot of things.... And then in addition to that, when I did some counting here (of our internal capacity data), I noticed that this would go on at these times of day and so on. So now I've got these ideas about how we can make the department function more efficiently. ... And then you look at these things that have worked, it's apparent to you from cross-pollinating all this information why it is and there's still a little bit of intuitive filling in the blanks."

Immersion in the internal and external evidence provided Clancy with deep insight into the problems affecting Fast-Track. Moreover, the recommendations for improving FastTrack offered in previous reports were based on 'good ideas' that were well supported in the literature: 'I just kept coming back to the same recipe as had been suggested beforehand'. Thus, Clancy concluded that the problem with Fast-Track was that its implementation had been undermined by resource allocation and patient selection criteria. With the problem reformulated, Clancy moved on to engaging stakeholders.

\section{Engaging Stakeholders and Generating Evidence-Based Alternatives}

Dr Clancy formed a working party and presented a 17 page report of the evidence he had collected and analysed. Under Clancy's leadership, the working party evaluated two alternative strategies for streaming patients: (1) two streams of Admit or Discharge, and (2) three streams of Resuscitation, Acute and Fast-Track. The first strategy was rejected because EDIS patient volumes suggested it 'would not conform to the ideal Fast Track clientele endorsed by the literature' (Working Party Update). The second strategy was already in use but ineffective. Principles on how to better implement this strategy were derived from the literature. First, evidence supporting early input from senior medical staff was 'so compelling 
April L. Wright, Raymond F. Zammuto, Peter W. Liesch, Stuart Middleton, Paul Hibbert, John Burke and Victoria Brazil (2016)

that it is perhaps the single greatest requirement of a successful Fast-Track service' (Working Party Report). Second, the literature indicated 'the overall gain in efficiency' of a Fast-Track unit was related to the extent to which resources - both staff and space - were quarantined from the rest of the ED (Working Party Update). Third, the 'defining characteristic' of a FastTrack patient was the shortness of expected processing time (Update).

These evidence-based principles helped Dr Clancy and the working party generate ideas for how to resource and select patients for Fast-Track. At a combined forum for medical and nursing staff, Clancy presented alternative ideas for reforming Fast-Track. To facilitate evidence-based discussion, he provided executive summaries of the literature in pamphlet form:

"Clancy of course presented various ideas to us and there was discussion about what would and wouldn't work. It wasn't like a dictatorship where we were presented with a plan and that was it. We all had the opportunity to have input." (I-5)

The working party used stakeholder feedback to refine their ideas. They also incorporated the results of an internal Staff Satisfaction Survey. As they evaluated and refined alternatives for resourcing Fast-Track, Clancy continued to explore the practical feasibility of these alternatives using current and predicted activity levels based on EDIS data. Through this process of fitting general principles, derived from external evidence, to internal evidence capturing the local context, the working party consolidated their ideas into a 'detailed evidence-based model' for Fast-Track (Working Party Report).

\section{Committing to an Evidence-Based Solution and Implementation}

The model recommended by Dr Clancy's Working Party comprised the following elements: (1) three streams, with patients in Resuscitation treated in order of urgency and patients in Fast-Track and Acute treated in order of arrival; (2) patient selection criteria 
April L. Wright, Raymond F. Zammuto, Peter W. Liesch, Stuart Middleton, Paul Hibbert, John Burke and Victoria Brazil (2016)

adapted from previous studies; (3) hours of operation estimated from EDIS data on patient volumes and peak arrivals; (4) autonomous staffing, with doctor and nursing needs calculated by extrapolating medical and nursing productivity rates reported in the literature; and (5) structural redesign of ED spaces to quarantine physical space for FastTrack. Each recommendation in the Working Party's report was justified by evidence which helped to persuade ED staff and hospital executives to make a commitment to implementing the Working Party's recommendations. Underpinning this commitment was trust in Dr Clancy as an evidence-based practitioner:

"Most people felt there wasn't too much about patient flow that he hadn't read or thought about before. So you kind of go, 'Well, you might as well just leave it to him. If he can 't sort it out, then no one else can'." (I-20)

After the Working Party's recommendations were accepted, hospital management funded the restructuring of the physical layout of the ED and staff were trained in the appropriate application of the revised patient selection criteria. Substantive improvements in efficiency were gained from the implementation of Fast-Track, including reduced patient waiting times and greater staff satisfaction. As a doctor who had experience of working in Fast-Track before and after its redesign commented:

"It works better for the whole department. It flows more efficiently. [...] The way it's designed, set up and run is very, very good for everyone. You get a lot of positive patient feedback about Fast-Track now." (I-23)

\section{The Importance of the decision maker and the context}

We have articulated a process for EBM decision-making that could, on the face of it, be universally applicable. However, 'opening up' the decision-maker and the context of the decision reveals insights that were important to the success of this particular process. These insights are summarised in Figure 1 and discussed below. 
April L. Wright, Raymond F. Zammuto, Peter W. Liesch, Stuart Middleton, Paul Hibbert, John Burke and Victoria Brazil (2016)

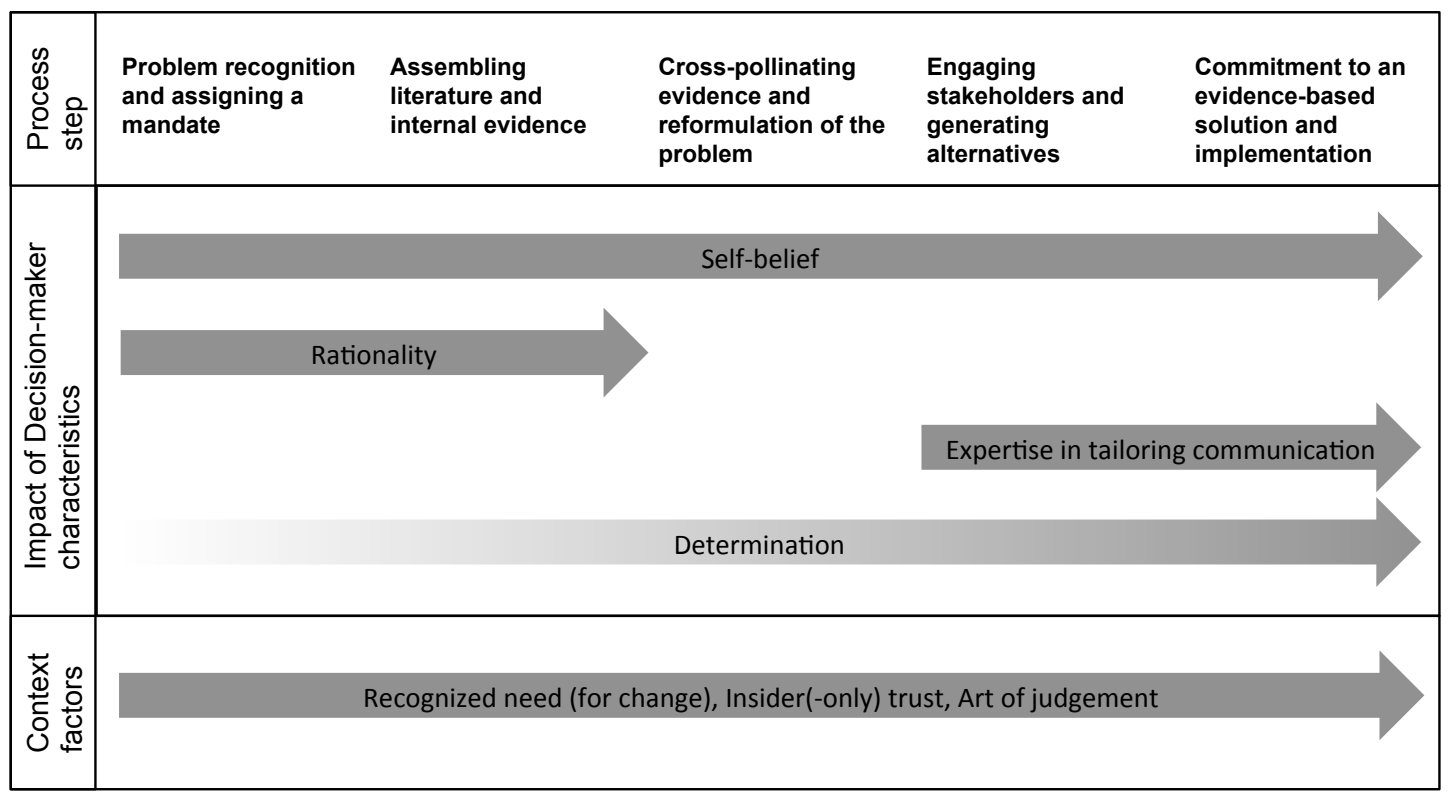

Figure 1: Decision-maker and context factors in relation to the EBM decision process

\section{Opening up the decision-maker}

A number of Clancy's personal characteristics and abilities were intrinsic to the development and execution of the EBM process. The first of these to note - and quite prominent in the data

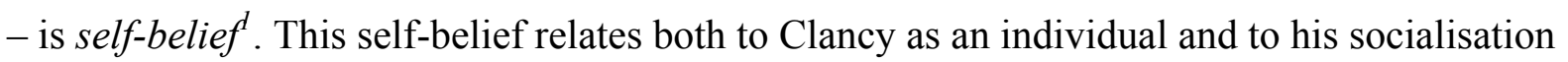
within his chosen field:

"I suppose I'm one of those people that doesn't need to impress anyone but myself and so medicine allows me to do that... I come here and be myself and that's good."

Self-belief allows Clancy to assume a mandate to address the Fast-Track problem, and legitimates intuitively 'playing around' with the evidence he gathers. If Clancy was not so sure of whom he is - a clinician fully immersed in the context and familiar with diagnostic

\footnotetext{
${ }^{1}$ While Clancy's self-belief may be related to his status as a physician, our data suggests that self-belief is an intrinsic personal quality of Clancy. Numerous doctors with similar medical training and experience as Clancy were of the opinion that Clancy's personal qualities - his determination, confidence, self-belief - were specific to him and critical to his success. They indicated that not every doctor would have been as effective as Clancy because they might not possess these personal qualities.
} 
April L. Wright, Raymond F. Zammuto, Peter W. Liesch, Stuart Middleton, Paul Hibbert, John Burke and Victoria Brazil (2016)

clues that may be incomplete - he would not be confident in making a leap of faith in reformulating problems and possible solutions:

"Start looking for reasons why I think that is and then you know you look at these things that have worked [...] and there's still a little bit of intuitive filling in of the blanks."

Moreover, Clancy recognises that his confidence persuades stakeholders to engage with the ideas he offers: "It helps if you are confident in your own assessment ... that's almost a personality thing." Self-belief was also important at the end of EBM process when it was balanced with Clancy's awareness of the potential for implementable action:

"I'm careful not to promise more than what I think I can deliver [...] [Fast-Track] was doable I think. I did that because I said I would."

Self-belief was clearly an important personal characteristic throughout the EBM process. In contrast, another characteristic that might be assumed to be evident throughout the process - rationality - was more apparent in the early phases. For example, it was evident in Clancy's initial interest in an EBM approach:

"I'm a rational kind of person. I like to know the rationale of things and I feel quite happy acting a certain way if I know the rationale behind it."

This preference for rationality led to Clancy taking on the challenge of gathering evidence (internally and from literature) although he recognised that others might not need the details: 'There are a lot of situations which it's not necessary for everyone to know the rationale for everything.'

Later in the process, a focus on rationality was less necessary and Clancy's expertise in tailoring communication became more prominent, particularly in meeting the needs of time-pressured colleagues in order to engage them:

"... it would be nice if provided with the same information that I have, people could arrive at all the same conclusions but there just isn't time for that [...] people are willing for something new, they want someone to come along and change things. So the trick is just to tell people what you think needs to be done, give them enough rationale to digest and get on board..." 
April L. Wright, Raymond F. Zammuto, Peter W. Liesch, Stuart Middleton, Paul Hibbert, John Burke and Victoria Brazil (2016)

Clancy's expertise in tailoring communication was multi-dimensional. First, it included skills in assembling written materials into convenient formats - "I put the literature summary into a sort of pamphlet form and people could read it if they wanted to." Second, he demonstrated the ability to present ideas in persuasive, economical language:

"Doctors are more concerned with scientific methodology and things like that [...but...] people's attention spans aren't that long in the final analysis. They like to know that they can look into the evidence behind something if they want to. But by the same token, if they trust you that you've done a thorough job on things..."

Finally, he maintained consistency in how the key ideas were communicated: 'I just kept pedalling the message.'

In the latter stages of the process another characteristic became apparent (although it can be implicitly regarded as present throughout): determination. This determination was linked to Clancy's self-belief: ‘...if everyone was interested in seeing things through in the same level of detail I am, they'd all be welcome.' It was also linked to a belief in the power of sustained thought and effort:

"There aren't too many problems that can withstand sustained consideration from someone as long as someone's prepared to take it on."

However, Clancy also made a judgement about whether sustained effort on his part would have an impact on the intended stakeholder audience and actually lead to an implemented solution: 'I don't want to waste my time doing something that will not penetrate people's behaviour.'

Interestingly, the four personal characteristics of the decision-maker that our analysis 'opened up' is that they are not concerned, in the main, with the aspect of the process that makes it evidence-based; that is, the actual assembly of literature and internal evidence. Instead, these characteristics provide a possible means of identifying the 'right' person to take on this kind of decision problem, and they also suggest how they might drive the process to completion. 
April L. Wright, Raymond F. Zammuto, Peter W. Liesch, Stuart Middleton, Paul Hibbert, John Burke and Victoria Brazil (2016)

\section{Opening up the decision context}

In comparison to the decision-maker, aspects of the context are not so easily ascribed to particular stages of the EBM decision process. Indeed, one of the most important factors, the recognised need for a decision on how to change Fast-Track, preceded the start of the process: 'Fast-Track was such a terrible place to work before, that when we were setting it up the thought of having to spend a whole day at Fast-Track was soul destroying' (I-8). By the outset of the decision process, matters had reached the edge of desperation: 'We can't do business like this for the next ten years. This will drive everybody mad' (I-3).

Despite the recognised need for change, the decision process could not be driven by 'just anyone', however well-grounded in evidence the recommended solution might be. The eventual solution to the Fast-Track problem decided on by Dr Clancy was quite similar to an earlier proposal presented by an external management consultancy team, which was not perceived to be legitimate: 'The hospital paid nearly a million dollars but because it was an external review nobody paid any attention to it - who are they to tell us what to do?'(I-17). Stakeholders in this context were clear that an acceptable solution would have to come from an insider: 'Dr Clancy's worked here and he knows how the system works' (I-3). It was important that the decision maker was a trusted insider - 'one of our own people' (I-17) because the art of judgement was seen to be intrinsic to the medical profession (and therefore would not be within the capabilities of an outsider):

"Medicine is just great. There's no black and white about this. It's all grey and it's just shades of grey [...] It's not science. It's all art. It's how you pull the right things together to try and get the right decision in the end" (I-16).

"I follow the evidence but within the evidence there is always that little bit of physician judgement. [...] I'm a great believer that medical training is very much an apprenticeship. It's not something you learn in books and I think it's all about role models" (I-7). 
April L. Wright, Raymond F. Zammuto, Peter W. Liesch, Stuart Middleton, Paul Hibbert, John Burke and Victoria Brazil (2016)

Since the stakeholder community is comprised of medical professionals who value the art of judgement so highly, evidence by itself would never be convincing without an advocate from this community to 'bring it to life':

"He blows me away. He puts up the data and the equations and the mathematics and it's like shit, you know. If he's put that much thought and that much process and that much passion into it then I'd be horrified to think anyone would disagree" (I-9).

The evidence remains important, but it has an impact on stakeholders partly because it supports the (somewhat intuitive) judgements made by the decision-maker, rather than being persuasive in and of itself. This meant that sometimes the evidence could even be implicit:

"He's summarised but I don't think he's sort of presented it as a critical review of what actually needs to be done [...] I don't know, he might have done that critical appraisal in his head..." (I-3).

In sum, as with the personal characteristics we discussed above, opening up the context reveals a number of key factors that complement the use of evidence. These contextual factors suggest that evidence is necessary but not sufficient for an EBM decision process to reach an acceptable solution. These contextual factors are entirely appropriate for the medical domain in this case where day-to-day clinical judgement is required whenever diagnostic evidence is inconclusive. This also implies that the decision-maker has to match up to the stakeholder community's expectations about demonstrating the art of judgement. Our data suggest that in this context, where there was a recognised need for change, the EBM decision-maker still had to be a trusted insider and a skilled artist able to convince stakeholders of his judgement with or without an explicit display of evidence.

\section{Discussion}

Our study of Fast-Track-revealed an evidence-based process involving five stages: (1) problem recognition and assigning a mandate; (2) assembling literature and internal evidence; (3) cross-pollinating evidence and reformulating the problem; (4) engaging stakeholders and 
April L. Wright, Raymond F. Zammuto, Peter W. Liesch, Stuart Middleton, Paul Hibbert, John Burke and Victoria Brazil (2016)

generating evidence-based alternatives; and (5) commitment to an evidence-based solution and implementation. Progression through these stages was led by a physician manager who systematically sought out and evaluated the best available internal and external evidence to generate alternative solutions.

In some respects, the EBM decision process we found resembles those in prior studies in decision-making and change management. The stages are reminiscent of rational decisionmaking studies reporting that managers facing structured problems should try to search for and evaluate information (Hickson et al., 1986; Langley, 1989; Mintzberg et al., 1976; Nutt, 1984; Witte, 1972) through analytic comprehensiveness (Fredrickson, 1984), procedural rationality (Dean and Sharfman, 1996) and discovery processes of intelligence gathering and evaluation (Nutt, 2008). The change management literature has also long acknowledged the need for change agents trusted by stakeholders. These similarities raise the possibility that EBM simply provides a new way of framing issues and problems without changing these issues and problems or the most effective ways to deal with them. We do not, however, believe this to be the case in general, and our study provides specific advances.

Addressing the general point first, what distinguishes EBM from other decision processes is the explicit and systematic use of scientific evidence, in concert with other sources of evidence, to inform decision-making. But we agree that empirical investigation of how this might occur in practice has been lacking to date. By unpacking how EBM is enacted inside an actual organisation, our study illustrates how evidence is brought to life inside organisations through social processes involving decision-makers and stakeholders operating within the situational realities of their context. In this way, we contribute to the EBM literature by providing rare insights into EBM in action. 
April L. Wright, Raymond F. Zammuto, Peter W. Liesch, Stuart Middleton, Paul Hibbert, John Burke and Victoria Brazil (2016)

Our study extends prior work by opening up of the role of the decision-maker and decision context in shaping the EBM decision process. We identified four relevant personal characteristics of the decision-maker: self-belief, a preference for rationality, expertise in tailoring communication, and determination. In relation to the context, three factors were prominent: a recognised need for change, insider (only) trust; and stakeholder regard for the art of judgement. Thus, the key theoretical insight that is generalisable from our case (Ridder, Hoon and McCandless Baluch, 2014) is that a fit between the personal characteristics of the decision-maker and the demands of the context - person-context fit - is important in arriving at an implementable decision through an EBM process. Thus, we extend Swan and coauthors' (2012) notion that evidence is co-produced by decision-makers and stakeholders by showing how co-production through EBM requires person-context fit. Our findings also advance understanding by contributing to debates centred on the four key criticisms of EBM identified at the outset of the paper. We address each of these below.

\section{EBM privileges rationality}

A criticism noted by several scholars is EBM's privileging of rationality and the scientific method in managers' decision processes (eg Bartenuk, 2014; Learmonth, 2006, 2008; Tourish, 2013). Philosophically this privileging is problematic because it ignores multiple epistemologies in conducting management research (Learmonth, 2006); pragmatically it is problematic because overemphasising rationality as a mode of knowing downplays intuition, which is important for creative problem solving, innovation and effective decision-making in dynamic organisational environments (Sadler-Smith and Burke, 2009; Sadler-Smith and Shefy, 2007; Sinclair and Ashkanasy, 2005; Taggart and Robey, 1981; Vance, Groves, Paik and Kindler, 2007). These problems are illustrated by Erez and Grant's (2014) call to teach managers to 'separate data from intuition' when making EBM decisions. 
April L. Wright, Raymond F. Zammuto, Peter W. Liesch, Stuart Middleton, Paul Hibbert, John Burke and Victoria Brazil (2016)

To an extent, our study counters criticism that EBM privileges rationality by showing how EBM is enacted by interplay between rationality and intuition. The decision-maker in our study had a preference for rationality and expressed this by methodically reviewing scientific literature and 'number crunching' hospital data. However, the decision-maker had to draw upon intuition to 'cross-pollinate' and make sense of the patterns within and across different types of data. Consistent with Eisenhardt's (1989a; 1999) findings that managers develop intuition as they engage with operational information, our study suggests that rationality and intuition reinforce each other in the practice of EBM. Cross-pollinating between empirical literature and local data during an EBM decision process increases holistic understanding of the problem confronting the organisation and pattern recognition of how contextual factors might impact alternative solutions.

This insight, however, points to a possible limitation of EBM in practice. Interplay between rationality and intuition in the collection and analysis of literature and internal evidence requires skill and time. Clancy's training and his clinical role as a user of medical evidence put him in a more favourable position to engage with evidence than would be common for most managers who may not have his skills in evidence interpretation nor the time for doing it. Thus, EBM may not be as readily achievable in contexts where repositories of reader-friendly summaries of evidence are not available and have to be constructed by untrained and time-poor practitioners, which is more typically the case for organisational problems.

\section{Evidence is incomplete and insufficient}

Echoing the preceding discussion, a second criticism of EBM is that the evidence base in management and organisation studies is often insufficient or incomplete as a guide for management decision-making (Arndt and Bigelow, 2009; Tranfield et al., 2003). Our study 
April L. Wright, Raymond F. Zammuto, Peter W. Liesch, Stuart Middleton, Paul Hibbert, John Burke and Victoria Brazil (2016)

lends weight to this criticism by suggesting there is a strong relationship between a convergent evidence base and ease of implementing an EBM decision process. In our study, the research literature supplied agreement on cause-and-effect relationships (early doctor input increases effectiveness, resource quarantining increases efficiency) which resonated with personal experiences of ED staff and could be translated into alternative solutions for the design of Fast-Track. Our study suggests that EBM decision processes may be particularly suited to operations management problems since this sub-field in organisation and management studies has shown itself to be well-suited to formal scientific approaches and thus has a well-developed literature of this kind.

The nature of the problem in our study brings to the surface important limitations to the general applicability of EBM. The problem was operational, non-urgent, structured by defined goals and measurable outcomes, and self-contained within a department. It is clear from our study, and from the findings of previous studies in the decision-making literature (Mintzberg and Westley, 2001; Nutt, 1984, 2008) that rational-analytic approaches like EBM are well-suited to these types of organisational problems. For more complex and system-wide problems in large organisations and for problems involving longer-term strategic change processes (Mintzberg and Waters, 1990), implementing EBM is expected to be a more contested process. In our study, the relatively small set of stakeholders shared similar perspectives on the value of evidence and from whom it could be trusted, and used their power to resist outsider-driven operational changes. In contrast, complex strategic problems involve many diverse stakeholders and political contests (Hickson et al., 1986; Pettigrew, 1973; Pfeffer, 1981), rendering agreement on what (and who) is and is not legitimate evidence less likely. Power and politics may play out with competing groups supporting, resisting and mobilising different sources of evidence, potentially stalling EBM. Further research is needed to explore if and how EBM decision processes can be applied in practice 
April L. Wright, Raymond F. Zammuto, Peter W. Liesch, Stuart Middleton, Paul Hibbert, John Burke and Victoria Brazil (2016)

to strategic problems and how this process differs from operations management problems, especially under conditions when the evidence base is insufficient and incomplete.

\section{How EBM plays out in particular contexts is unclear}

A third criticism stems from limited empirical investigation of EBM in practice (Reay et al., 2009), which means the nuances of how EBM decision processes are enacted in different organisational contexts is unclear (Arndt and Bigelow, 2009; Briner et al., 2009). Our study speaks directly to this debate by offering an illustrative case of EBM in a public hospital emergency department in Australia. In our study, there was a close fit between what the decision-maker leading the EBM process supplied (self-belief, preference for rationality, expertise in tailoring communication and determination) and what the organisational context demanded (change, a trusted insider and the art of judgement being applied to evidence).

Thus, our findings suggest that an EBM process is more likely to produce an implementable decision when the personal characteristics of the decision-maker fit the requirements of the context.

Challenging prior studies showing limited adoption of EBM in healthcare management in practice (Kovner et al., 2000; Kovner and Rundall, 2006; Swan et al., 2012; Walshe and Rundall, 2001), our study offers future researchers a starting point for investigating the range of contextual conditions under which EBM is likely to be effective and ineffective. We speculate that the particular personal characteristics and contextual factors we identified in our study of a hospital setting are likely to be relevant in other organisational settings involving medical professionals and potentially other types of professional organisations, such as engineering and law. However, given that our analysis of EBM decision processes is limited to a single case study, more research is needed to further 
April L. Wright, Raymond F. Zammuto, Peter W. Liesch, Stuart Middleton, Paul Hibbert, John Burke and Victoria Brazil (2016)

elaborate our findings. Comparative case studies could unpack the impact of personal characteristics, such as self-belief and determination, on whether and how a decision-maker incorporates evidence into their decision processes and with what consequences in different organisational contexts. Nevertheless, we believe our key insight related to the importance of person-context fit in EBM decision processes is likely to be theoretically generalisable and we encourage future research that explores how the fit between EBM and the specific social realities of the decision context varies from situation to situation.

\section{The role of the situated expertise of the decision-maker has been lost}

A final criticism concerns EBM's lack of attention to the 'situated expertise' of the decisionmaker in the decision process (Morrell, 2008). Although EBM was inspired by the movement towards evidence-based practice in medicine (Pfeffer and Sutton, 2006; Rousseau, 2006), the concept of 'situated expertise' has largely been ignored in the transfer of ideas from medicine to management (Morrell, 2008). Situated expertise, defined as "the proficiency and judgment that individual clinicians acquire through clinical experience and clinical practice", is core to evidence-based medicine (Sackett et al., 1996, p. 71). By devaluing the role of situated expertise, EBM has been criticised for missing the point that evidence-based practice has been successful in improving decision-making in medicine because clinicians have the expertise and experience to make judgments that contextualise scientific evidence to local situations.

To a degree, our study supports this critique. Our study was set in what might be described as a cross-over context from evidence-based medicine to EBM. The decisionmaker was a physician who sought to adapt his knowledge of evidence-based practice to an operations management problem. In this medical/management situation, the decision-maker possessed the situated expertise needed for the early stages of an evidence-based process and 
April L. Wright, Raymond F. Zammuto, Peter W. Liesch, Stuart Middleton, Paul Hibbert, John Burke and Victoria Brazil (2016)

stakeholders placed value on situated expertise in the engagement and implementation stages. Thus, our study highlights the potential for situated expertise to be an enabler of evidencebased practice in management just as it is in medicine.

We argue, therefore, that there is a need to (re-)legitimate situated expertise in the practice and teaching of EBM. Historically, the rhetoric of EBM has emphasised scientific evidence as a replacement for traditional management decision-making grounded in personal experience (Pfeffer and Sutton, 2006; Rousseau, 2006). Our findings suggest that the notion of evidence replacing a manager's personal experience is short-sighted. This is not to say that we disregard the value of evidence, but instead we argue that situated expertise - which is underpinned, in part, by personal experience and judgment - is needed in the handling, adaptation and communication of this evidence. Our study indicates that evidence does not speak for itself, and neither does it allow decision processes to be enacted without contextsensitive judgment.

These insights point to the need for a more balanced view of EBM in which managers engage with evidence in context as an integral part of practice grounded in situated expertise. This view has implications for future research and for how management education and development programs are constructed by business schools. Future research is needed to better understand the art of judgement that is core to situated expertise, as well as the different forms in which this expertise is enacted, encountered and valued in different contexts. Management educators can then incorporate this understanding into their teaching to support managers-to-be to develop situated expertise, which we suggest is essential to enacting EBM in practice in useful and meaningful ways.

\section{Conclusion}


April L. Wright, Raymond F. Zammuto, Peter W. Liesch, Stuart Middleton, Paul Hibbert, John Burke and Victoria Brazil (2016)

Evidence-based management, as a "science-informed practice of management" (Rousseau, 2012, p. xxiii), has been criticised for privileging rationality, downplaying the divergent evidence base in management and organisation studies, conducting limited empirical investigation of EBM in actual practice and devaluing situated expertise. Our paper contributes to debates over these critiques of EBM by 'opening up' the decision process, decision-maker, and context in a qualitative study of EBM in a hospital emergency department in Australia. While we find support, to a degree, for some of the criticisms of EBM, our study reveals important insights into EBM decision processes and the role of person-context fit in engaging with evidence and stakeholders to reach an implementable and effective decision. These insights provide for a more context-sensitive application of EBM with potential benefits for public administration and effective management in the private sector, as well as a more nuanced understanding for management educators of how EBM is enacted in practice through situated expertise. We encourage further research to examine how the interrelationships we observed between EBM decision process, decision-maker and context play out in other empirical settings, including in professions other than health care. 
April L. Wright, Raymond F. Zammuto, Peter W. Liesch, Stuart Middleton, Paul Hibbert, John Burke and Victoria Brazil (2016)

\section{References}

Allison, G. (1971). Essence of Decision: Explaining the Cuban Missile Crisis. Boston, MASS: Little, Brown and Company.

Arndt, M. and B. Bigelow (2009). 'Evidence-based management in health care organizations: A cautionary note', Health Care Management Review, 34(3), pp. 206-213.

Baack, S. (2007). Book Review of 'Hard facts, dangerous half-truths and total nonsense: Profiting from evidence-based management', Academy of Management Learning and Education, 6(1), pp. 139-141.

Baba, V. V. and F. HakemZadeh (2012). 'Toward a theory of evidence-based decision making'. Management Decision, 50(5), pp. 832-867.

Bartenuk, J. 2014. 'Introduction: Bringing life to a correlation of 0.14: Teaching EBM engagingly and convincingly', Academy of Management Learning and Education, 13(1), pp. 102-103.

Bennis, W. G. and J. O'Toole (2005). 'How business schools have lost their way', Harvard Business Review, 83, pp. 96-104.

Briner, R. B., D. Denyer and D.M. Rousseau (2009). 'Evidence-based management: Concept cleanup time?' Academy of Management Perspectives, 23(4), pp. 19-32.

Butler, R. (1990). 'Decision-making research: Its uses and misuses. A comment on Mintzberg and Waters: Does decision get in the way?' Organization Studies, 11(1), pp. 11-16.

Casio, W. F. (2007). 'Evidence-based management and the marketplace for ideas', Academy of Management Journal, 50(5), pp. 1009-1012.

Cohen, M. D., J.G. March and J.P.Olsen (1972). 'A garbage can model of organizational choice', Administrative Science Quarterly, 17(1), pp. 1-25.

Corbin, J. and A. Strauss (2008). Basics of Qualitative Research (Third ed.). Thousand Oaks, CA: Sage.

Cyert, R. M. and J.G. March (1963). A Behavioral Theory of the Firm. Englewood Cliffs, NJ: Prentice Hall.

Daft, R. (1995). Organization Theory and Decision. St Paul, MN: West Publishing Company.

Dane, E. and M.G. Pratt (2007). 'Exploring intuition and its role in managerial decisionmaking', Academy of Management Review, 32, pp. 33-54.

Das, T. K. and B.-S. Teng (1999). 'Cognitive biases and strategic decision processes: An integrative perspective', Journal of Management Studies, 36(6), pp. 757-775. 
April L. Wright, Raymond F. Zammuto, Peter W. Liesch, Stuart Middleton, Paul Hibbert, John Burke and Victoria Brazil (2016)

Dean, J. W. and M. P. Sharfman (1996). 'Does decision process matter? A study of strategic decison-making effectiveness', Academy of Management Journal, 39(2), pp. 368-396.

Denzin, N. K. (1989). The Research Act: Theoretical Introduction to Sociological Methods. Englewood Cliffs, NJ: Prentice Hall.

Eisenhardt, K. (1989a). 'Making fast decisions in high-velocity environments', Academy of Management Journal, 32, pp. 543-577.

Eisenhardt, K. M. (1989b). 'Building theories from case study research', Academy of Management Review, 14(4), pp. 532-550.

Eisenhardt, K. and M. Zbaracki (1992). 'Strategic decision making', Strategic Management Journal, 13, pp. 17-37.

Eisenhardt, K. M. (1999). 'Strategy as strategic decision making', Sloan Management Review, 40, pp. 65-72.

Eisenhardt, K. M. and M. Graebner (2007). 'Theory building from cases: Opportunities and challenges', Academy of Management Journal, 50(1), pp. 25-32.

Erez, A. and A. Grant (2014). 'Separating data from intuition: Bringing evidence into the management classroom', Academy of Management Learning and Education, 13(1), pp. 104-119.

Flick, U. (2002). An Introduction to Qualitative Research (2nd ed.). London: Sage.

Fredrickson, J. W. (1984). 'The comprehensiveness of strategic decision processes: Extension, observations, future directions', Academy of Management Journal, 27, pp. 445-466.

Golden, B. R. (1992). 'The past is the past - Or is it? The use of restrospective accounts as indicators of past strategy', Academy of Management Journal, 35, pp. 848-860.

Hickson, D. J., R.J. Butler, D. Cray, G.R. Mallory and D.C. Wilson (1986). Top Decisions: Strategic Decision-making in Organizations. San Francisco: Jossey-Bass.

Klingebiel, R. and A. De Meyer (2013). 'Becoming aware of the unknown: Decision making during the implementation of a strategic initiative', Organization Science, 24(1), pp. 133-153.

Kovner, A. R., J.J. Elton and J. Billings (2000). 'Evidence-based management', Frontiers of Health Services Management, 16(4), pp. 3-22.

Kovner, A. R. and T.G. Rundall (2006). 'Evidence-based management reconsidered', Frontiers of Health Services Management, 22(3), pp. 3-22.

Langley, A. (1989). 'In search of rationality: The purposes behind the use of formal analysis in organizations', Administrative Science Quarterly, 34(4), pp. 598-631. 
April L. Wright, Raymond F. Zammuto, Peter W. Liesch, Stuart Middleton, Paul Hibbert, John Burke and Victoria Brazil (2016)

Langley, A., H. Mintzberg, P. Pitcher, E. Posada and J. Saint-Macary (1995). 'Opening up decision making: The view from the black stool', Organization Science, 6(3), pp. 260279.

Laroche, H. (1995). 'From decision to action in organizations: Decision-making as a social representation', Organization Science, 1, pp. 62-75.

Learmonth, M. (2006). 'Dialogue: "Is There Such A Thing As Evidence-Based Management?": A Commentary on Rousseau's 2005 Presidential Address', Academy of Management Review, 31, pp. 1089-1093.

Learmonth, M. (2008). 'Evidence-Based Management: A Backlash Against Pluralism in Organizational Studies', Organization, 15, pp. 283-291.

Leonard-Barton, D. (1990). 'A dual methodology for case studies: Synergistic use of longitudinal single site with replicated multiple sites', Organization Science, 1(3), pp. 248-266.

March, J. G. (1988). Decisions and Organizations. Oxford: Basil Blackwell.

March, J. G. (1991). 'How decisions happen in organizations?' Human-Computer Interaction, 6, pp. 95-117.

March, J. G. and H.A. Simon (1958). Organizations. New York: John Wiley and Sons.

Miles, M. B. and A.M. Huberman (1994). Qualitative Data Analysis: An Expanded Sourcebook. London: Sage.

Miller, C. and D. Ireland (2005). 'Intuition in strategic decision making: Friend or foe in the fast-paced 21st century', Academy of Management Executive, 19(1), pp. 19-30.

Miller, C. C., L.B. Cardinal and W.H. Glick (1997). 'Retrospective reports in organizational research: A reexamination of recent evidence', Academy of Management Journal, 40(1), pp. 189-204.

Mintzberg, H., D. Raisinghami and A. Theoret (1976). 'The structure of unstructured decisions', Administrative Science Quarterly, 21, pp. 246-275.

Mintzberg, H. and J. Waters (1990). 'Does decision get in the way?' Organization Studies, 11(1), pp. 1-6.

Mintzberg, H. and F. Westley (2001). 'Decision making: It's not what you think', MIT Sloan Management Review, 42(3), pp. 89-93.

Morrell, K. (2008). 'The narrative of 'Evidence Based Management': A polemic', Journal of Management Studies, 45(3), pp. 613-635.

Nutt, P. (1984). 'Types of organizational decision processes', Administrative Science

Quarterly, 29, pp. 414-450. 
April L. Wright, Raymond F. Zammuto, Peter W. Liesch, Stuart Middleton, Paul Hibbert, John Burke and Victoria Brazil (2016)

Nutt, P. (2008). 'Investigating the success of decision making processes', Journal of Management Studies, 45(2), pp. 425-455.

Padgett, J. F. (1980). 'Managing garbage can hierarchies', Administrative Science Quarterly, 25, pp. 583-604.

Pettigrew, A. (1973). The Politics of Organizational Decision Making. London: Tavistock.

Pfeffer, J. (1981). Power in Organizations. Marshfield, MA: Pitman.

Pfeffer, J. and G.R. Salancik (1974). 'Organizational decision making as a political process: The case of a university budget', Administrative Science Quarterly, 19, pp. 135-151. Pfeffer, J., and R. Sutton (2006). Hard Facts, Dangerous Half-truths, and Total Nonsense: Profiting from Evidence-Based Management. Boston: Harvard Business Review.

Pfeffer, J. and R.I. Sutton (2007). 'Suppose we took evidence-based management seriously: Implications for reading and writing management', Academy of Management Learrning and Education, 6, pp. 153-155.

Plambeck, N. and K. Weber (2009). 'CEO ambivalence and responses to strategic issues', Organization Science, 20(6), pp. 993-1010.

Reay, T., W. Berta and M.K. Kohn (2009). 'What's the evidence on evidence-based management?' Academy of Management Perspectives, 23(4), pp. 5-18.

Ridder, H.-G., C. Hoon and A. McCandless Baluch (2014). 'Entering a dialogue: Positioning case study findings towards theory', British Journal of Management, 25, pp. 373-387.

Rodrigues, S. B. and D.J. Hickson (1995). 'Success in decision making: Different organizations, differing reasons for success', Journal of Management Studies, 32(5), pp. 655-678.

Rousseau, D. (Ed.). (2012). The Oxford Handbook of Evidence-Based Management. New York: Oxford University Press.

Rousseau, D. M. (2006). 'Is there such a thing as 'evidence-based management'? Academy of Management Review, 31(2), pp. 256-269.

Rousseau, D. M. and S. McCarthy (2007). 'Educating managers from an evidence-based perspective', Academy of Management Learning and Education, 6(1), pp. 84-101.

Rynes, S. L., J. Bartenuk and R. Daft (2001). 'Across the great divide: Knowledge creation and transfer between practitioners and academics', Academy of Management Journal, 44(3), pp. 340-356.

Rynes, S. L., T.L. Giluk and K.G. Brown (2007). 'The very separate worlds of academic and practitioner periodicals in Human Resource Management: Implications for evidencebased management', Academy of Management Journal, 50(5), pp. 987-1008. 
April L. Wright, Raymond F. Zammuto, Peter W. Liesch, Stuart Middleton, Paul Hibbert, John Burke and Victoria Brazil (2016)

Sackett, D. L., W.M.C. Rosenberg, J.A.M. Gray, R.B. Haynes and W.S. Richardson (1996). 'Evidence based medicine: What it is and what it isn't', British Medical Journal, 312, pp. 71-72.

Sadler-Smith, E. and L.A. Burke (2009). 'Fostering intuition in management education: Actions and resources', Journal of Management Education, 33(2), pp. 239-262.

Sadler-Smith, E. and E. Shefy (2004). 'The intuitive executive: Understanding and applying "gut feel" in decision-making', Academy of Management Executive, 18(4), pp. 76-91.

Sadler-Smith, E. and E. Shefy (2007). 'Developing intuitive awareness in management education', Academy of Management Learning and Education, 6(2), pp. 186-205.

Simon, H. A. (1955). 'A behavioral model of rational choice', Quarterly Journal of Economics, 69, pp. 99-118.

Simon, H. A. (1976). Administrative behavior: A study of decision-making processes in adminsitrative organization (3rd ed.). New York: Free Press.

Simon, H. A. (1945, 1997). Administrative Behavior: A Study of Decision-Making Processes in Administrative Organization. New York: Free Press.

Sinclair, M. and N.M. Ashkanasy (2005). 'Intuition: Myth or decision making tool?' Management Learning, 36, pp. 353-370.

Sutcliffe, K. M. and G. McNamara (2001). 'Controlling decision-making practice in organizations', Organization Science, 12(4), pp. 484-501.

Swan, J., A. Clarke, D. Nicolini, J. Powell, H. Scarborough, C. Roginski, E. Gkeredakis, P. Mills and S. Taylor-Phillips (2012). 'Evidence in Management Decisions (EMD) Advancing Knowledge Utilization in Healthcare Management', Final Report. In N. H. S. a. d. R. programme (Ed.).

Taggart, W. and D. Robey (1981). 'Minds and managers: On the dual nature of human information processing and management', Academy of Management Review, 6, pp. 187-195.

Thomas, H. and A.E. Wilson (2011). "Physics envy', cognitive legitimacy or practical relevance: Dilemmas in the evolution of management research in the UK', British Journal of Management, 22, pp. 443-456.

Thompson, J. D. (1967). Organizations in action. New York: McGraw Hill.

Tourish, D. (2013). "'Evidence-based management" or "evidence-oriented organizing"? A critical realist perspective', Organization, 20(2), pp. 173-192. 
April L. Wright, Raymond F. Zammuto, Peter W. Liesch, Stuart Middleton, Paul Hibbert, John Burke and Victoria Brazil (2016)

Tranfield, D., D. Denyer and P. Smart (2003). 'Towards a methodology for developing evidence-informed management knowledge by means of systematic review', British Journal of Management, 14, pp. 207-222.

Useem, M., J. Cook and L. Sutton (2005). 'Developing leaders for decision making under stress: Wildland firefighters in the South Canyon Fire and its aftermath', Academy of Management Learning and Education, 4(4), pp. 461-485.

Van de Ven, A. H. and A. Lifschitz (2013). 'Rational and reasonable microfoundations', Academy of Management Perspectives, 27(2), pp. 156-172.

Vance, C. M., K.S. Groves, Y. Paik and H. Kindler (2007). 'Understanding and measuring linear-nonlinear thinking style for enhanced management education and professional practice', Academy of Management Learning and Education, 6(2), pp. 167-185.

Walshe, K. and T.G. Rundall (2001). 'Evidence-based management: From theory to practice in health care', Milbank Quarterly, 79(3), pp. 429-457.

Witte, E. (1972). 'Field research on complex decision making process - the phase theory', International Studies of Management and Organization, 56, pp. 156-182. 